This item was submitted to Loughborough's Research Repository by the author.

Items in Figshare are protected by copyright, with all rights reserved, unless otherwise indicated.

\title{
Climatology of flooding in the United States
}

PLEASE CITE THE PUBLISHED VERSION

http://dx.doi.org/10.1093/acrefore/9780199389407.013.123

\section{PUBLISHER}

(C) Oxford University Press (OUP)

\section{VERSION}

AM (Accepted Manuscript)

\section{PUBLISHER STATEMENT}

This work is made available according to the conditions of the Creative Commons Attribution-NonCommercialNoDerivatives 4.0 International (CC BY-NC-ND 4.0) licence. Full details of this licence are available at: https://creativecommons.org/licenses/by-nc-nd/4.0/

\section{LICENCE}

CC BY-NC-ND 4.0

\section{REPOSITORY RECORD}

Villarini, Gabriele, and Louise Slater. 2019. "Climatology of Flooding in the United States". figshare. https://hdl.handle.net/2134/24451. 


\section{Climatology of Flooding in the United States}

2 Gabriele Villarini and Louise J. Slater

3

4

5

6

7

8

9

10

11

\section{Summary}

Flood losses in the United States have increased dramatically over the course of the past century, averaging US\$7.96 billion in damages per year for the 30-year period ranging from 1985 to 2014. In terms of human fatalities, floods are the second largest weather-related hazard in the United States, causing an average of 82 deaths per year between 1986 and 2015.

Given the wide-reaching impacts of flooding across the United States, the evaluation of flood-generating mechanisms and of the drivers of changing flood hazard are two areas of active research.

Flood events can be driven by a variety of physical mechanisms, including rain and snowmelt, frontal systems, monsoons, intense tropical cyclones, and more generic cyclonic storms. However, flood frequency analysis has traditionally been based on statistical analyses of the observed flood distributions that rarely distinguish among these physical floodgenerating processes. In reality, flood frequency distributions are often characterized by 'mixed populations' arising from multiple flood-generating mechanisms, which can be challenging to disentangle.

Temporal changes in the frequency and magnitude of flooding have also been the subject of a large body of work in recent decades. The science has moved from a focus on the detection of trends and shifts in flood peak distributions towards the attribution of these changes, with particular emphasis on climatic and anthropogenic factors, including urbanisation and changes in agricultural practices. A better understanding of these temporal changes in flood peak distributions, as well as of the physical flood-generating mechanisms, will enable us to move forward with the estimation of future flood design values in the context of both climatic and anthropogenic change.

Keywords: flooding, United States, detection, attribution, mixed distributions, urbanization, agriculture, flood frequency, hydrology, precipitation. 


\section{Introduction}

Flood losses in the United States have increased dramatically over the course of the past century (Pielke and Downton 2000, Downton et al. 2005), averaging US\$7.96 billion in damages per year for the 30-year period ranging from 1985 to 2014 (NOAA National Weather Service 2016). The most costly recent floods in terms of economic damages were the Midwest floods of 1993 and 2008, followed by the 1997 floods in the Northern Plains and on the U.S. West Coast, with costs ranging from $\$ 35$ to $\$ 4.5$ billions respectively (National Climate Data Center 2016). The growth in damages arising from these major flood events can be related to both climatic drivers - namely the increasing frequency of average and extreme precipitation events - and societal or economic drivers - i.e. the concentration of population and assets in flood-exposed areas (e.g. Pielke and Downton 2000). As a result, major (or 'billion-dollar') floods have been increasing by about 5\% per year (Smith and Katz 2013), and projections based on the statistical relationship between socio-economic drivers and annual precipitation for 1929-1998 suggest that a mere 1\% increase in annual precipitation may lead to a 6.5\% increase in annual flood losses (Choi and Fisher 2003). In terms of human fatalities, floods are the second largest weather-related hazard in the United States, with an average of 82 deaths per year between 1986 and 2015 (versus 130 for heat and 70 for tornadoes; Office of Services 2016). Overall, flooding has major societal and economic impacts across the United States, with the total value of properties insured through the National Flood Insurance program reaching over \$1 trillion in the past decade (Kousky and Michel-Kerjan 2015). This chapter examines the physical mechanisms that are driving the occurrence of these flood events in the United States, and provides a broad overview of how flood hazards have changed over the twentieth and twenty-first centuries, and of the methods used to attribute the different drivers of flooding.

\section{Flood generating mechanisms}

\section{Flood agents and mixed populations}

Traditionally, our understanding of flood frequency has been based on mathematical modelling of the observed historical flood records. However, these empirical analyses tend to lack a physically-based understanding of the flood frequency distribution, based on the underlying flood processes. As described by Klemeš (1974, pg. 2): “The empirical data representing a hydrologic event are treated as a collection of abstract numbers that could pertain to anything or to nothing at all”. Klemeš argued that a solid characterisation of flood 
frequency could arise only from the physics of the phenomena, rather than from the mathematics (Klemeš, 1993, pg. 168). The examination of flood agents, i.e. the physical mechanisms that are conducive to flooding across different areas of the United States, presents multiple benefits: from a scientific perspective, it advances our understanding of the interrelationship between hydrology, atmospheric and climate sciences; and from an engineering perspective it is vital for improving our ability to predict floods and to plan the appropriate design structures.

The distribution of flood events at any given location in space and time often results from a combination of different types of flood-generating weather systems and storms (e.g. Villarini 2016, Berghuijs et al. 2016). These combined distributions are known as 'mixed populations', and it can be challenging to determine which flood peaks result from the different processes. The official U.S. guidelines for determining flood frequency, known as Bulletin 17-B (U.S. Interagency Advisory Committee on Water Data 1982) acknowledged this difficulty, and indicated that flooding could be produced by different mechanisms across the USA, such as rain and snowmelt (e.g. Sierra Nevada), intense tropical cyclones, or more generic cyclonic storms (e.g. Atlantic and Gulf Coasts). Bulletin 17-B highlighted the need to identify the 'agents' of flooding, and warned that a simplistic stratification of flood records (e.g. based on calendar periods distinguishing between spring and summer flood events) was not 'hydrologically reasonable.' The authors wrote that '[i]f the flood events that are believed to comprise two or more populations cannot be identified and separated by an objective and hydrologically meaningful criterion, the record [should] be treated as coming from one population' (pg. 16). Thus, while Bulletin 17-B identified the need for a better understanding of flood processes to improve flood frequency estimation, it provided limited guidance on how to achieve such an understanding; similar conclusions hold with the upcoming Bulletin 17-C.

At the continental scale, a number of studies have attempted to provide a synthesis of the variety of spatial and seasonal flood generating mechanisms across the United States. One of the most comprehensive discussions and frameworks for the interpretation of flooding in terms of mixtures of different flood generating mechanisms was developed by Hirschboeck (1987, 1988, 1991) in a series of studies investigating the physical flood-driving processes. More recently, Villarini (2016) used circular statistics to examine the seasonality of flooding at 7506 U.S. Geological Survey (USGS) stations in terms of different major flood agents, including tropical cyclones, atmospheric rivers, snowmelt, and monsoon. Berghuijs et al. 
(2016) tackled this issue from a hydrologic perspective: at 420 catchments across the United States, they related the annual maximum peak discharge to maximum or weekly daily precipitation, maximum soil moisture dependent precipitation excess or snowmelt. Overall, the studies in this area suggest that, across large areas of the United States, different parts of the flood peak distributions are controlled by specific agents.

\section{Rainfall- and snowmelt-driven flood events}

The issue of mixed flood-generating mechanisms has been addressed through a variety of assumptions and modeling approaches since the early 1980s, with an initial focus on rainfalland snowmelt-driven flood events. Waylen and Woo (1982) first described flooding in the Cascade Mountains in terms of snowmelt and rainfall events. The authors used antecedent precipitation to differentiate between the snowmelt and rainfall populations, and fit a Gumbel distribution to the flood events associated with each flood-generating process. They found that by compounding the two distributions at each site they obtained a better characterization of the observed annual flood series. This approach was further formalized by Rossi et al. (1984), who developed a statistical framework to characterize flood distributions at 39 stream gages in Italy in terms of the two-component extreme value distribution. They argued that the flexibility introduced by the mixture of two exponential distributions provided a more realistic representation of the annual maximum flood peak records; one component (the 'basic distribution') allowed the characterization of the more common and less severe flood events, while the other one (the 'outlying distribution') was geared toward the description of the more severe flood events that would be qualified as outliers using a single distribution. This framework led to an improved fit across a wide range of flood magnitudes that would not have been possible by using just one distribution. Diehl and Potter (1987) used data from 29 stream gaging stations to describe flooding in Wisconsin in terms of mixtures of two populations. They used a calendar-based approach to stratify the records into spring and summer floods occurring before and after May $20^{\text {th }}$. A similar approach was followed by Todhunter (2012), who examined the issue and implications of mixed flood distributions for the Red River of the North by describing the flood record in terms of snowmelt and rainfall peaks. Because the majority of the flood peaks were associated with snowmelt (85\%) rather than rainfall (15\%), the mixed distribution closely resembled that based on the whole record, with minor departures at the higher and lower tails. Jarrett and Costa (1988) also examined flood peak time series in the Colorado Front Range and stratified the records in terms of snowmelt- and rain-generated flood peaks. 
Merz and Blöschl (2003) examined the idea of mixtures of different flood agents from a catchment-based, rather than an atmospheric circulation-based perspective. They considered five flood types (long-rain floods, short-rain floods, flash floods, rain-on-snow floods, and snowmelt floods), and focussed on different indicators, including storm duration and rainfall depth/snowmelt, catchment state (i.e. soil moisture conditions), runoff response dynamics (e.g. fast or slow response), flood seasonality, and spatial coherence. They also acknowledge that these flood types do not likely have sharp boundaries in terms of their processes and characteristics. Shaw and Riha (2011) examined long-term (50+ years of data) records from three watersheds in the state of New York. They found that about 20\% of the annual flood peak records were associated with annual maximum rainfall, about $20 \%$ with annual maximum snowmelt events, and about 60\% with moderate rainfall and saturated soil conditions. The authors also investigated potential future changes in annual maximum peak discharge values by developing a compound distribution to account for the different flood generating mechanisms, and examined flood response for changes in the contribution of each flood agent.

\section{Frontal systems, monsoons and tropical cyclones}

Rainfall-related flood events have been further examined in terms of storm types, with particular emphasis on tropical cyclones, and their controls on the upper tail of the flood peak distributions. Waylen (1991) examined the role of tropical cyclones on flooding in the Santa Fe River basin in Florida over the 1928-1988 period. He found that tropical-cyclone related flood magnitudes were larger than those associated with summer convective events. Webb and Betancourt (1992) focussed on the Santa Cruz River in Arizona and characterized the flood frequency in terms of three different populations: floods associated with frontal systems, with monsoons, and with tropical cyclones. They showed the effects of each of these flood generating mechanisms on flood frequency and discussed the limitations of flood frequency analyses in the context of mixtures. Murphy (2001) described flood flows in Massachusetts in terms of three agents: tropical cyclones, ice-jam-release, and ordinary flooding (i.e. not caused by either of the other two agents). He found that the probability that one of the studied Massachusetts stream gauges would have an annual maximum associated with a tropical cyclone was 0.0515/year, but also that the peak flows caused by these storms were statistically different from the other annual flood peaks. Overall, he showed that the flood peaks associated with tropical cyclones and ice-jam releases would be classified as outliers if a single distribution was used. Alila and Mtiraoui (2002) stratified the annual flood 
series of the San Francisco River at Clifton (Arizona) into two main classes (monsoon and frontal systems), with the monsoon (frontal) systems controlling the lower (upper) tail of the distribution.

More recent work has investigated the spatial variability of the influence of tropical cyclones on flood peaks across the United States. Villarini and Smith (2010) showed that flood drivers in the eastern United States present a strong spatial variability: snowmelt and extra-tropical cyclones tend to be responsible for much of the flooding in the north-eastern and south-eastern United States, while tropical cyclones contribute to a large fraction of annual maximum flood peaks in Florida ( 40\%) and the U.S. Eastern Seaboard, ranging from South Carolina to New Jersey. These insights were further developed in Smith et al. (2011), who provided a detailed characterization of the spatial structure and temporal evolution of rainfall and flooding associated with tropical and extra-tropical cyclones. The relationship between tropical cyclones and flooding in Texas was examined by Villarini and Smith (2013), who showed that tropical cyclones were responsible for up to $18 \%$ of the annual maximum flood peak records, especially along the Gulf of Mexico, even though their control on the upper tail of the flood peak distribution was smaller than in the eastern United States (see Villarini et al. (2014) for an extensive discussion on flooding from tropical cyclones).

\section{Statistical modelling of mixed populations}

From a statistical perspective, different approaches have been proposed and developed to model these mixed distributions. Alila and Mtiraoui (2002) described three different approaches to account for heterogeneity in flood frequency depending on the assumptions that one is willing to make in terms of occurrence of different flood events, and whether the data are stratified a priori based on the flood generating mechanisms (see also discussion in Singh et al. (2005)).

The first approach builds on the additive rule of probability and assumes that the flood populations are independent of one another, so any given annual maximum peak discharge must be associated with a single flood generating mechanism (e.g. the annual maximum is assumed to be caused either by a tropical or monsoonal storm, but not by both) (e.g. Jarrett and Costa 1988, Webb and Betancourt 1992). Each subset is then fit separately and combined using the additive rule of probability. The disadvantage of this approach is that the records must be subset, so larger sampling uncertainties occur in the estimated parameters of the 
fitted distributions and long-term historical datasets are required to classify the different flood events.

The second approach does not require sub-setting the annual maximum time series into two or more populations, but assumes that two flood peaks occur sequentially during the year. One example of this would be snowmelt flood peaks occurring in the spring, followed by rainfall flood peaks in the winter (e.g. Waylen and Woo 1982, Diehl and Potter 1987). In such a case, the spring flood events are assumed to be homogenous, and are fit with a given distribution. The same is done for the winter events. Using the multiplicative rule of probability, the two distributions are then combined. The advantage of this approach is that the sample size used for the fitting is not reduced, since one event per year is associated with each of the identified flood generating mechanisms. The downside, however, is that it does not allow for different types of storms to occur in the same season, which may not be a realistic assumption (as discussed above, this approach is not recommended by Bulletin 17B).

Finally, the third approach does not necessitate any a priori stratification of flood peaks, but requires selecting the number of mixtures for the distributions, estimating the parameters for each distribution and choosing the mixing parameter(s) to weight the mixed distribution (e.g. Rossi et al. 1984, Alila and Mtiraoui 2002, Grego and Yates 2010). Following this line of research, recent studies have provided insights on the use of finite mixture models, including improved estimation of the parameters and the associated standard errors (e.g. Grego and Yates 2010, Grego et al. 2015). The strength of this approach is that the flood peaks do not need to be stratified in terms of flood generating mechanisms. However, this is also the weakness of the approach because it favours a purely statistical perspective over the physical interpretation of the flood peak records, and therefore is vulnerable to the abovementioned criticisms by Klemeš (1974).

Substantial progress has thus been made in recent years in incorporating a physical understanding of flood-generating mechanisms in flood frequency analysis. However, more effort is required to tackle this problem successfully, as it is not an easy task to accomplish and is fraught with complications. To move forward successfully, hydrologists must engage with climate and atmospheric scientists in order to understand the physical processes leading to different kinds of events. At the same time, hydrologists would also benefit from a closer relationship with applied statisticians to formalize the statistical modeling. Overcoming these obstacles would advance the science of flooding and allow for a better and more accurate 
estimation of design discharge values which are so critical in in a number of engineering applications.

\section{Temporal changes in flood peaks (Annual Maxima and Peaks Over Threshold)}

Historically, the occurrence of major floods in different parts of the globe has been viewed through the lens of stationarity, using probability distributions that are invariant to translations in time (e.g. Brillinger 2001), and that have no abrupt and gradual changes or periodicities (e.g. Salas 1993). This assumption of stationarity has served as the foundation for engineering structures and flood design. However, in the early $21^{\text {st }}$ century it has become widely accepted that, as a result of the influence of human activities and their influence on the climate system, increasing temperatures and the associated moisture-holding capacity of the atmosphere have altered the frequency with which extreme precipitation events occur (e.g. Karl et al. 2009, Trenberth 2011). Increases in the frequency and magnitude of heavy and extreme precipitation events are now well-established across the United States, and flooding may intensify as a result (Georgakakos et al. 2014). In fact, changes in peak flow distributions are so common that the concept of stationarity in flood risk and water management has been declared 'dead' (Milly et al. 2008). These changes are particularly problematic for planning, management, and forecasting of major floods. While many water managers still operate under the assumption of stationarity, it is increasingly recognized that flood planning and 'design floods' (and more generally any climatic extremes (e.g. Cheng et al. 2014)) should be revised in the context of nonstationarity, to incorporate the notion that future floods may be magnified in comparison with historical estimates (e.g. Vogel et al. 2011).

Two indicators are typically used to assess whether floods are changing over time: changes in the magnitude (are floods getting bigger or smaller?) and in the frequency (are they occurring more or less often than before?) of flood events. Within these two categories, changes may be gradual (occurring in the form of trends), or abrupt (referred to as shifts, or step changes) (e.g. Rougé et al. 2013). Step changes are often the result of anthropogenic influences on water networks, such as impoundment or water abstraction. Trends, however, are of a progressive, incremental nature, often resulting from changes in climate or land use. These changes in the magnitude or frequency of flooding may arise from a combination of causes, including atmospheric changes (e.g. precipitation type, timing, phase, volume, and 
temperature), land use and land cover (e.g. agriculture, urbanization) and anthropogenic water management (including dams, diversions, and abstraction).

\section{Detection of changes in flood magnitude}

\section{Trends in flood magnitude}

To assess changes in the magnitude of flooding, the annual maximum series (AMS) is typically employed because it is a simple indicator that only requires extracting the largest daily flood in every year (referred to as the $100^{\text {th }}$ percentile, $\mathrm{Q}_{100}$, or $\mathrm{Q}_{\max }$ ). Traditionally, the non-parametric Mann-Kendall test (Mann 1945, Kendall 1975) is used to detect monotonic changes in the average magnitude of the annual maximum series (i.e. progressive increases or decreases over time). The null hypothesis of the Mann-Kendall test can thus be described as the probability that $\left[Y_{j}>Y_{i}\right]$ is equal to 0.5 , where time $T_{j}>T_{i}$, as long as there is no serial correlation in the values of $\mathrm{Y}$ (Helsel and Hirsch 1992). Because the Mann-Kendall test is non-parametric, it allows the investigator to make minimal assumptions about the distribution of the peak flow data (which are typically skewed) and the type of changes over time (it tests for monotonic patterns, which would include, for instance, linear, exponential, logarithmic changes). The Spearman test is also used, though less frequently. In comparison with the Mann-Kendall test, it is also nonparametric and works with the ranks of the data sample. The Spearman's estimator is the same as the Pearson's correlation coefficient computed on the ranks and has a similar power to the Mann-Kendall test for detecting trends in the time series (Yue et al. 2002).

Numerous studies have been conducted since the end of the twentieth century to detect trends in the magnitude of flood flows across the USA. While strong regional patterns of increasing versus decreasing flows have been found, generally speaking, the trends in the highest flows $\left(\mathrm{Q}_{100}\right)$ often tend to be non-statistically significant (e.g. Lins and Slack 1999) or less significant than other streamflow percentiles (McCabe and Wolock 2002), and generally display far less spatial coherence (Lins and Slack 1999). The difficulty in detecting significant trends in flow maxima arises from their strong inter-annual variability, which requires much stronger trends (or longer time series) in comparison with lower discharge quantiles before the trends can become statistically significant (Wilby 2006). Therefore, comparing trends detected in short annual maximum time series with those found in longer records may result in notable discrepancies. 
Regionally, increases in flood flows have been more marked in the Midwest than across the rest of the United States. Studies using discharge records from hundreds of stream gauges have found strong increases in flood flows in the region (Kundzewicz et al. 2005, Villarini et al. 2011) occurring mostly as a result of change points, rather than trends (Villarini et al. 2011). In the Upper Mississippi, changes in agricultural land use over the last two centuries, alongside an earlier timing of snowmelt runoff, appear to have been a major contributor to the increases in flood magnitudes, particularly in the second half of the twentieth century (Knox 2001). The observed increases in the magnitude of large floods spread from the Midwest right across the Northeastern USA (Hirsch and Ryberg 2012), with upward trends in flood magnitude across New England (Collins 2009). Many of the changes detected in the eastern USA (Villarini and Smith 2010), and in the Delaware basin (Smith et al. 2010) are associated with abrupt changes in the peak flow distributions, often linked to regulation. Across the rest of the eastern USA, increases in high flows have been relatively common (Groisman et al. 2001): upward trends in peak discharges have been detected in New England (Armstrong 2012) and in annual flood trend magnitudes across the eastern USA/Atlantic coast (Collins et al. 2014). In the Mid-Atlantic USA, long discharge time series also showed upward trends in annual flood magnitude, with step changes occurring around 1970 (Armstrong 2013), while in Maine, annual peak flows have increased notably during the past 50-100 year period (Hodgkins 2010). central USA where streamflow is snowmelt-dominated (see e.g. Barnett et al. 2005), precipitation is generally stored in the form of high-altitude snowpacks that melt in the warm season. Increases in mean temperature occurring since the late 1940s have progressively reduced these snowpacks and altered snowmelt patterns (Dettinger and Cayan 1995): the upward shift in spring and early summer temperatures that occurred in the mid-1980s has produced an earlier timing of snowmelt runoff (McCabe and Clark 2005). Concomitantly, the earlier timing of peak streamflows in the winter/spring and autumn has resulted in a retreat in the streamflow centre of volume date (Hodgkins et al. 2003), so higher flood peaks are produced from runoff in the early spring months (Knowles and Cayan 2002). While the centre-of-volume date, or hydrograph centroid, is widely used to interpret the effects of warming temperature on hydrographs (see Groisman et al. 2001 for an illustration), it is not considered a robust indicator, because flow contributions other than snowmelt influence the indicator and can produce false centre-of-volume values (Whitfield 2013). In California, flow 
responses are dependent on catchment elevation and the seasonality of the climate forcing, so streamflow responses have been most accentuated in middle 'moderate' latitudes (Dettinger and Cayan 1995). More generally however, the western USA has witnessed widespread decreases in flood flow magnitudes across the Rocky Mountains and the arid Southwest (Hirsch and Ryberg 2012).

\section{Step changes in flood magnitude}

In addition to progressive changes in the annual maxima which can be detected through trend analysis, abrupt changes or shifts, also referred to as step changes, can be detected through change point analysis. Statistical methods for distinguishing between the two are still an active area of research in hydrology (e.g. Rougé et al. 2013). Step changes or shifts occur when streamflow maxima increase suddenly, rather than as a progressive trend. The vast majority of the available statistical tests seek for changes in the mean and/or variance (e.g. Villarini et al. 2009). Complicating factors can obscure the detection of step changes, including the presence of multiple shifts in the data, the lack of a-priori knowledge as to their location and magnitude, and the effect of skew within the hydrological maxima time series.

Various statistical techniques exist to detect change points in the mean of hydrologic maxima. Using 50 USGS stations with at least 100 year-long records and documented changes in discharge occurring from regulation or diversion, Villarini et al. (2009) found that the Pettitt test best detected the step changes when compared with other change point tests. The Pettitt test (Pettitt 1979) is a non-parametric test that is used for detecting changes in the mean of a distribution; it is based on the Mann-Whitney rank-based statistic, and determines whether two samples come from the same population. When used for observing shifts in extremes, the sensitivity of the Pettitt test increases with the magnitude of the shift, record length, centrality of location of the shift within the time series, and low variability in the data (Mallakpour and Villarini 2015a). Villarini et al. (2009) showed that significant change points could be detected in almost half of the studied long-term discharge records across the conterminous USA. In contrast, a slightly simpler approach for step-change detection is to seek for a statistical difference in the data between two fairly long (e.g. multi-decadal) time periods. McCabe and Wolock (2002) used standardized departures of the maximum daily streamflow (i.e. subtracting the long-term mean from the flow values, and dividing by the standard deviation) at 400 sites, and found differences between two time periods (1941-70 and 1971-99) using the Student's t-test. Few significant step changes were found for the maximum daily flow, in comparison with mean and low flows, as above in the case of trend 
analysis. Collins (2009) used time series of average standardized departures to detect step changes and found abrupt shifts in New England flood peaks around 1970, coincidental with a shift to a positive phase in the North Atlantic Oscillation.

In addition to detecting changes in the mean of annual maximum time series, the flood literature is beginning to consider changes in variance. Generally, extreme events tend to be more sensitive to shifts in hydro-climatic variance than to shifts in the mean (e.g. Katz and Brown 1992). The Lombard test (Lombard 1987), like the Pettitt test, is non-parametric and rank-based and used to test for changes in the mean, but also allows to consider changes in variance. Such changes might occur as a result of both climatic and anthropogenic influences (dams, reservoirs, changes in water management), and can obscure changes in the mean (Kundzewicz and Robson 2004). The performance of the Lombard test increases with the magnitude and significance of the changes in variance, the sample size, and the centrality of location of the change point within the time series, and is reduced with the presence of changes in the mean (Nayak and Villarini 2016).

\section{Detection of changes in flood frequency}

While most studies have focussed on the detection of gradual and abrupt changes in the magnitude of flood events, comparatively little has been done on changes in flood frequency across the United States. Frequency-based methods enable the detection of changes in how often events of a given magnitude occur. They do not provide the same information as trends in flood magnitude, and may not necessarily exhibit the same sign (floods may be getting larger, but occurring less frequently (e.g. Svensson et al. 2005, Petrow and Merz 2009) or significance levels (Mallakpour and Villarini 2015b).

Two types of data are typically used for quantifying changes in the frequency of flood events: the annual maximum series (AMS) and the partial duration series (PDS) (Langbein 1949). The AMS approach considers only the maximum flow in each year, so it can be used to see how frequently floods of a given size occurred over a set historical record. However, one inherent difficulty with the AMS is that by considering only the maximum flow in each year, the resulting records are poorly adapted for semi arid or arid regions where floods may occur at a sub-annual frequency (e.g. only every 5-, 10- years or more). The PDS approach, in comparison, records all flows above a set discharge threshold $\left(q_{0}\right)$, which can be either a given flow magnitude or a flow of a given exceedance probability (e.g. the flow that is exceeded twice, or four times per year on average). For this reason it is commonly referred to 
as the 'peaks-over-threshold' (POT) method (e.g. Smith 1984, Leadbetter 1991), as it consists in using only a fraction of the time series, i.e. the largest flood events.

Different approaches are used to select the appropriate $q_{0}$ threshold. The first consists in selecting a fixed value of $q_{0}$ and counting the frequency of floods exceeding that chosen value. By choosing the lowest annual flood, for instance, at least one flood in each year can be included (Langbein 1949). If a high threshold is selected, then the years with no true flood will be counted as zeroes, and thus can be included using strictly positive trend detection methods, such as Poisson regression, to obtain a precise estimation of changes in the frequency of flooding. A second approach consists in setting $q_{0}$ at the threshold that is exceeded on average $n$ times per year (e.g. two events per year, Mallakpour and Villarini 2015b). This latter approach allows to scale POT to enable a comparison between rivers of different size. Thus, the $q_{0}$ and $\beta$ parameters (i.e. the threshold value and the slope coefficient to quantified changes over time) are estimated from a fixed sample size at every site. Overall, the choice of the most appropriate threshold remains relatively arbitrary, as long as it is high enough to justify the model assumptions and low enough to capture sufficient observations (Dupuis 1998).

Peaks-over-threshold methods have gained in popularity in recent years, as they enable the investigator to determine whether the rate of occurrence parameter is a linear function of time, i.e. whether non-stationarity can be detected within the non-normally distributed time series. The principal advantage of the peaks-over-threshold approach is that it considers a greater number of events than the AMS approach, and theoretically provides a more representative characterisation of changes in the frequency of flows. It also allows the user to select different thresholds, thus controlling the number of floods that are included in the analysis (Lang et al. 1999). However, the flood data (daily or instantaneous) that are listed are not necessarily independent, as in the AMS approach. A frequency distribution is fit to the time series of floods exceeding $q_{0}$, and typically, the partial duration series is formulated using the Poisson distribution (Kirby 1969, Smith and Karr 1986).

A comparison of the statistical efficiency of annual flood series and peak-over-threshold methods reveals that for floods of the same size and up to the five-year recurrence interval, recurrence intervals in the partial duration series (POT) tend to be smaller than those computed using the annual flood series (AMS) (Langbein 1949). Cunnane (1973) also showed that for the largest floods that occur the least frequently, the peaks-over-threshold approach had smaller sampling variance. 
In contrast with analyses of trends in flood magnitude, relatively little has been done on changes in flood frequency across the United States. The field of fluvial geomorphology first quantified the frequency of bankfull flows in river channels using the annual peak flow time series (Dury 1961, Leopold et al. 1964), and in more recent years, geomorphic studies have measured the effects of channel management (e.g. Booth 1991), catchment development and urbanisation (Booth and Jackson 1997) on changing flood frequency across the United States

\section{2 (Slater et al. 2015).}

Studies specifically focussed on detecting hydrologic trends in flood frequency across the USA are more recent. Collins (2009) documented increases in the recurrence of set flood magnitudes at seven gauges in New England before and after 1970. The peaks-over-threshold approach has been adopted even more recently. Armstrong et al. (2012) found widespread upward trends in the frequency of peaks above flood thresholds at 23 climate-sensitive New England stream gauges using the Mann-Kendall test. Mallakpour and Villarini (2015b) found widespread increases in frequency and magnitude across the Midwest, which were much more significant in terms of frequency than in terms of flood peak magnitude. Slater et al. (2015) measured POT trends in the number of days above the average 'channel capacity' at flood stage, and compared them with trends in flood hazard arising from changes in the capacity of river channels. The authors found increases in flood frequency across the Midwest and north-eastern USA, with a mix of upwards and downwards trends across the rest of the conterminous USA.

One difficulty with the POT method lies in selecting the threshold in an objective manner, given that large and small basins have different peak arrival times, with much flashier flows and steeper scaled peak discharges for the same return period in small versus large basins (Blöschl and Sivapalan 1995). In other terms, because flood peaks tend to last longer above flood levels in large versus small catchments, an increase in flood frequency of $n$ days per year will be proportionally more important in small channels. Thus, to meet the independence condition of separate peak events, it has been suggested that flood events should be separated 443 by a given number of days, adjusted by catchment size, e.g. 5+ the natural logarithm of the 444 basin area in square miles (e.g. Lang et al. 1999). Hence, to observe trends in the frequency of flood events above the National Weather Service's flood categories, Slater and Villarini (2016a) use an approach which detects trends in the frequency of independent events based on catchment size. 
Figure 1 shows a comparison of trend analyses that were performed to detect changes in the frequency, magnitude and duration of flood events over the 1965-2015 period at 3830 sites across the continental United States, Alaska, Hawaii and Puerto Rico. Large areas of the eastern United States, the Great Lakes region and the Midwest show increasing trends in the magnitude and frequency of flood events, while the south-eastern and western United States are mostly characterized by decreasing trends. The distinct regional pattern of increasing versus decreasing trends in flood magnitude (AMAX) is even more prominent when one focuses on the duration (NDAYS) of the flood events. The number of statistically significant trends is similar for flood magnitude and frequency across all sites (Figure 1, left column), however in climate-sensitive catchments, statistically significant trends are detected far more often in the frequency than in the magnitude of flood events (Figure 1, right column, 16\% of the time for NEVENTS, versus 6\% of the time for AMAX), in line with most of the conclusions and findings in the literature.

\section{Attribution of changes in flood hazard}

Following the extensive number of studies that have been published on the detection of flood trends across the United States, many research groups have now moved on to attempting to understand the causes of these changes, through attribution science. The idea behind attribution studies is to formally detect the drivers that are responsible for temporal changes in the magnitude and frequency of flood flows, whether they are gradual or abrupt (trends or step-changes). Attribution studies typically associate flood patterns with changes in land cover/land use, water management of river basins, and anthropogenically-driven climate change. They separate the relative influence or magnitude of each driver by decomposing the flood series behaviour in time. Merz et al. (2012) propose a distinction between 'soft' and 'hard' attribution studies. In the first case, the flood trends are attributed to certain drivers, but only in a speculative fashion through hypotheses and referrals to previous studies. 'Hard' attribution, on the other hand, would include the following three 'ingredients', namely (i) evidence of consistency, showing that the detected change is consistent with the assumed driver of change, (ii) evidence of inconsistency, showing that the change is inconsistent with changes due to alternative possible drivers, and (iii) a provision of confidence level associated with the attribution statement. At the time of writing (2012), the authors considered that no studies yet satisfied those three criteria because the published literature focussed only on consistency, generally through simple qualitative reasoning and without attempting to quantify the relationship between cause and effect. However, the wide range of 
approaches that have been used in attribution studies in the past few decades can also be laid out on a spectrum ranging from 'soft' to 'hard', or from the least to the most quantitative.

\section{Attribution of flooding to climate}

The attribution of trends in flood magnitude and frequency to changes in the climate system is possibly the largest area of flood attribution studies. Four main approaches can be distinguished to assess whether climate changes are expressed in flood flows, and will be elaborated: (i) simple spatial (visual) correlation and inference, (ii) the use of minimallyimpacted or 'climate-sensitive' gauges, (iii) approaches which explicitly measure the relationship between flooding and climate variables, and (iv) hydrologic modelling.

The simplest approach is that of spatial correlation between trends in precipitation and flooding on a purely visual level. Analyses of precipitation patterns across the conterminous USA have indicated that during the twentieth century, precipitation increased by approximately 10\% (Karl and Knight 1998) due to the heightened frequency of rainfall days and of heavy or extreme precipitation events (e.g. Field et al. 2012). Extreme precipitation events grew by $+3 \%$ per decade for 1931-1996, particularly over the region ranging from the central Great Plains to the southern Great Lakes (Kunkel et al. 1999), while the top 1\% of precipitation events increased by almost 20\% (Gutowski et al. 2008). These increases become greater towards the end of the century (Pryor et al 2009), and the amounts of rain falling as precipitation have been significantly above average since 1991 (Walsh et al. 2014). Regionally, the third National Climate Assessment indicates that heavy precipitation measured as the $99^{\text {th }}$ percentile of daily precipitation events - has increased more than would be expected from natural variations across the Northeast, Midwest, Puerto Rico, Southeast, Great Plains, and Alaska, but not in the Southwest, Hawaii or the Northwest (Walsh et al. 2014). The strongest increases (more than 30\% above average) are detected in the Northeast, Midwest, and upper Great Plains (Walsh et al. 2014), and the increases in the number of days with heavy precipitation (defined e.g. as the heaviest 1 percent of events, or using an extreme precipitation index) have been strongest over the Northeast and Midwest (Karl et al. 2009; Kunkel et al. 2013). These spatial trends have been correlated visually with trends in flooding: Mallakpour and Villarini (2015b) showed a strong visual correlation between the direction of trends in heavy rainfall and that of trends in flood magnitude and frequency over the central United States between 1962 and 2011. Slater et al. (2015) also pointed to the spatial correlation between detected trends in flood frequency and other studies that assessed 
changes in climate characteristics over the conterminous USA, such as the extreme precipitation index (Janssen et al. 2014).

A second approach tries to detect the hydro-climatic signal in flood flows by using only streamflow records obtained from 'climate sensitive' stations. A number of stream gauge networks were set up in the second half of the twentieth century with the purpose of enabling such attribution studies. The idea was to select sites with records that were sufficiently long to capture climatic variations (e.g. more than 50 years), and 'minimally affected', i.e. unimpaired by the various anthropogenic influences to river systems (e.g. regulation, abstraction, or flow augmentation). The first such network to be set up was the USGS Hydrologic Benchmark Network, or HBN (Leopold 1962), which aimed to provide long-term time series of flow and water chemistry in stations least affected by human activities. Now only a few dozen of the initial stations remain (Murdoch et al. 2005). Several decades later, in 1992, the USGS Hydro-Climatic Data Network (HCDN) was established, with 1,659 stations selected based on low basin development, lack of regulations/diversions, and record length (Slack and Landwehr 1992), and slightly less rigid selection criteria in data-sparse regions (Whitfield and Burn 2012). Many studies have used these minimally-impacted stream gauge networks to document climatically-driven trends in flood flows. The HCDN has been by far the most widely-used network (e.g. Lins and Slack 1999, McCabe and Wolock 2002, Lins and Slack 2005, Douglas et al. 2000, McCabe and Clark 2005). Lins and Slack (2005), for instance, used $435 \mathrm{HCDN}$ stations to investigate changes in the timing of annual flows. They found no systematic change across the conterminous USA and concluded that the increases in low to moderate flows were not accompanied by an increase in flooding.

Because the original HCDN flow records ended in 1988, many studies have sought to update and verify the original HCDN stream gauge selection. Collins (2009) selected 28 HCDN gauges not influenced by regulation (by reviewing peak flow qualification codes and water-data reports) with continuous data spanning 1951-2006; Armstrong et al. (2012) focussed on 23 of the same gauges; and Collins et al. (2014) use ten of the gauges over New England. Armstrong (2013) also reviewed HCDN stations for inclusion in their study, and retained only the records lacking regulation/diversion, with over 60 years of record reaching beyond 2009, and no less than 5\% of missing data. Hodgkins et al. (2003) used HCDN stations in New England with flows free of anthropogenic influences and at least 50 continuous years of record up to water year 2000. Many of these HCDN stations have now been discontinued, and due to the lack of updates, the network was progressively abandoned. 
In 2010, the Geospatial Attributes of Gages for Evaluating Streamflow (GAGES) network was established (Falcone et al. 2010). Of the 9324 stations in the network, 2061 were identified as being located in 'reference' catchments, i.e. least affected by anthropogenic influences. Reference sites were identified based on three criteria: (i) the hydrologic disturbance within the watershed had to be less than in $75 \%$ of all watersheds within the ecoregion (resulting from reservoirs, withdrawal, road density, and other factors); (ii) lack of regulation; and (iii) verification of satellite imagery for the presence of human activities. As a subset of the reference stations, the GAGES-II project also included an 'updated HCDN network', composed of 743 stations, distributed relatively homogeneously across the USA, and 203 of which have at least 60 years of data (Lins 2012). Surprisingly, the GAGES-II classification of 'reference' sites and the HCDN-2009 update are not very well known and have not yet been widely used for attributing climate drivers in flood studies. Slater et al. (2013) used GAGES-II reference sites to assess the relationship between trends in high flows $\left(\mathrm{Q}_{90}\right)$ and bed elevation, and found that short-term variability in flood flows altered riverbed level, capturing shifts in climate, and altering the frequency of overbank flows. Slater and Villarini (2016a) used predictors from GAGES-II (including the reference classification) to assess controls on the relationship between trends in precipitation and flood frequency.

In addition to the GAGES-II set of reference stream gauges, the 'Sentinel Watersheds' program was established by the USGS National Streamflow Information Program (NSIP) as a set of catchments that are minimally affected by human activities, and used for trend studies aiming to assess the effects of changes in climate, land use, and management on water resources (National Research Council 2004). The Sentinel Watersheds program is a network of 874 sites, including both HCDN stations and HBN stations, which are relatively free from anthropogenic influence (i.e. have no large reservoir upstream) and where $80 \%$ of the catchment area is within one single eco-hydrologic unit. See Whitfield and Burn (2012) for a comprehensive description of global reference hydrologic networks for trend analyses. Last,

572 the international Model Parameter Estimation Project (MOPEX, Duan et al. 2006) was 573 initiated in 1996 at the global scale to facilitate parameter estimation for hydrologic modelling and to bring together international hydrologists and land surface modellers. A large number of hydrologic records within MOPEX are from the United States (Schaake 2006) and provide hydrometeorological data (precipitation, temperature, and streamflow), a dominant soil type, and a dominant vegetation type. 
Because the existing 'minimally-impaired gauge' datasets were of variable quality and/or not inclusive of all USGS gauging stations, a number of studies developed their own reference classifications. Dettinger and Cayan (1995) selected five river basins in California where flow is 'wild or nearly unimpaired', with little development or landuse change. Slater et al. (2015) classified 401 USGS stream gauges based on their level of anthropogenic flow modification (least, intermediate, and most modified), by assessing the mean daily flow time series, USGS annual water data reports, maps and Google Earth aerial images, to determine if geomorphic effects on flood frequency varied according to the level of human interference in flow records. Hirsch and Ryberg (2012) selected 200 USGS stream gauges in the conterminous USA, with at least 85 years' length through water year 2008, in basins with little or no reservoir storage or urban development ( $<150$ persons $/ \mathrm{km}^{2}$ in 2000). Using these gauges, they analysed relationships between long-term flood records and global mean carbon dioxide concentration across four large regions of the conterminous USA, and found no evidence of a significant relationship after correcting for the effects of spatial and serial correlation. Groisman et al. (2001) used a network of collocated rain and streamflow gauges with more than 60 years of synchronous daily observations, and computed the number of days above the monthly $90^{\text {th }}$ and $99^{\text {th }}$ percentiles for $1961-1990$. To reduce the variance in flow data, eliminate noise, and facilitate the detection of climate-induced changes in flood frequency, they pooled these data and computed standardized regionally-averaged trends for comparison with changes in the frequency of heavy precipitation. They found that in the Western states, trends in heavy precipitation did not translate into flood records, suggesting that the decrease in snow cover extent is complicating the relationship between heavy precipitation and streamflow. In the eastern United States, on the contrary, where snowmelt only has a small fractional contribution to heavy runoff, the data revealed a significant relationship between the frequency of heavy precipitation and high streamflow, both annually and during months of maximum discharge.

A third approach which goes further than spatial correlation and the use of climatesensitive gauges aims to quantify the association between the time series of one variable (e.g. flood frequency) and the climate variable (e.g. annual rainfall). Relatively few studies have used this approach to detect changes in flooding. Slater and Villarini (2016a) observed time series of flood peaks and basin-averaged rainfall extremes tailored over the same time 609 periods, and quantified the association between the two. They showed that trends in flood frequency were more strongly driven by trends in total annual rainfall than trends in the 
frequency of heavy precipitation events, suggesting that flood hazard is more a function of changing overall basin wetness than of anomalous events.

Last, approaches that are based on hydrologic modelling typically attempt to reproduce the flow distribution over time, so if a divergence is found between the observed and modelled distributions, then the difference can be isolated and attributed to external (e.g. climate-driven) forcing rather than to natural internal variability (Harrigan et al. 2014). Hamlet and Lettenmaier (2007) forced the Variable Infiltration Capacity (VIC) hydrologic model with observed temperature data. They found that as a result of increasing temperatures and reduced spring snowpack, the flood risk had reduced in snowmelt-dominated basins and increased in the warm coastal basins of Washington, Oregon, and California. Other studies are mostly at the basin-scale. Davis Todd et al. (2007) used the VIC model with long-term records of flow, precipitation, and land-use in a rapidly-urbanizing basin in Indiana. By holding the climatology constant and modeling the land-cover changes, they showed that the increases in flows that occurred between 1940 and 2005 were not climate-driven, and that over two-thirds of peak flow events were not directly caused by the peak daily precipitation events. Similar hydrological attribution/modelling approaches can also be used to project the influence of specific drivers on flood flows in the future. Praskievicz and Chang (2011) simulated the impacts of climate change versus urban development in Oregon. They forced two catchment-scale models with statistically-downscaled data from seven GCMs with two scenarios of possible land use, and found that high flows were likely to increase by 69 to 80 percent for the high climate change scenario. Similarly, Jung and Chang (2011) used the Precipitation Runoff Modelling System to simulate future changes in the Willamette basin in Oregon under eight GCM scenarios, and found projected increasing trends in the top 5\% of streamflows associated with winter flooding.

While it is clear that precipitation plays a major role in flood events, it not yet wellunderstood whether flooding and climate modes can be related over longer timescales. Climate modes are patterns or indices that recur spatially, often in an oscillatory manner (e.g. Wang and Schimel 2003) over interannual and interdecadal time scales, and influence the atmospheric drivers of regional precipitation. By establishing a relationship between precipitation and these modes, it becomes possible to connect climate and flooding. This is a topic that has not been dealt with extensively, but one that could have large benefits for flood predictions by leveraging the memory of the climate system. Hamlet and Lettenmaier (2007) for instance showed that flood risks vary with the Pacific Decadal Oscillation (PDO) and the 
interannual El Nino-Southern Oscillation (ENSO). They found that the largest changes in flood patterns occurred when PDO/ENSO were in phase, especially in the southwestern United States. In the Mid-Atlantic region and New England, Armstrong (2013) found that increases in flood magnitude and frequency were related to the winter North Atlantic Oscillation phase. Collins et al. (2014), however, found little evidence of a relationship between flood-producing synoptic storms and the North Atlantic Oscillation (NAO)/ENSO over the eastern USA. Mallakpour and Villarini (2016) conducted a broad investigation of the relationship between long-term trends in peaks-over-threshold at 774 stream gauges and five climate indices affecting both the Atlantic and Pacific oceans, including the PDO, the NAO, the Southern Oscillation Index (SOI), the Atlantic Multidecadal Oscillation (AMO), and the Pacific-North American pattern (PNA). They showed that the variability in the frequency of peaks-over-threshold was driven by variability in the climate system, and in particular by the PNA.

\section{Attribution of flooding to dams and engineering structures}

Dams and impoundment structures have had notable effects on the distribution of flood flows across the continental USA. The widespread construction of dams throughout the twentieth century has had substantial influences on the spatial and temporal distribution of peak flows across the United States. Dams alter the natural flow regime by reducing the magnitude and frequency of high flows for the purpose of flood control, electric power generation, irrigation, local water use, recreational activities, and navigation (Poff et al. 1997). By the late 1980s, almost one million kilometres of rivers in the United States were already controlled by dams (Echeverria et al. 1989), and by the end of the twentieth century, 75000 dams were in place and capable of storing almost the equivalent of one year's runoff (Graf 1999). The largest of these dams have been shown to reduce the annual peak discharges by two-thirds and sometimes by up to 90\% (Graf 2006). At gauges on the Great Miami River, Hiwassee River, Red River at Fargo, and the Columbia River, for example, significant change points in the peak flow time series were detected as a result of regulation and diversions, i.e. in 1922 on the Great Miami River, 1942 on the Hiwassee River and Red River at Fargo, and 1938 on the Columbia River (Villarini et al. 2009).

The effects of dams on flood flows can also be indirect, due to the narrowing and simplification of river channels below the dam (Graf 2006, Van Steeter and Pitlick 1998). By reducing the capacity of river channels to contain flood flows, these geomorphic effects can heighten the frequency and inundation extent (Slater et al. 2015, Slater 2016). Such changes 
677 can occur over tens of kilometres beneath the dam (Gregory and Park 1974). High-flow that 678 is released immediately below dams is termed 'hungry' (Kondolf 1997) because it is sediment-starved: flows with reduced sediment concentration have excess energy and

680

681

682

683

684

685

686

687

688

689

690

691

692

693

694

695

696

697

698

699

700

701

702

703

704

705

706

707

708

709

transport capacity, so they erode the riverbed and banks until the riverbed material coarsens and a new equilibrium is reached, where the channel can no longer incise (Williams and Wolman 1984). The eroded sediment is deposited further downstream, resulting in channel aggradation lower in the basin (Schmidt and Wilcock 2009) and heightened flood flows (Stover and Montgomery 2001). Thus, as a result, dams create a redistribution of flood hazard at basin scales, as river channel capacity of stream channels is increased immediately below the dams (reducing flood frequency) and decreased lower in the basins (increasing flood frequency) (Slater et al. 2015). Flood attribution studies have focussed on two other areas specifically: the effects of urbanisation and agriculture on flood flows.

\section{Attribution of flooding to urbanisation}

In the United States, more than $80 \%$ of the population now lives in urban areas (US Census Bureau 2001). Urbanisation was considered by Leopold (1968) as the single most forceful land-use change affecting runoff, through its effects on the percentage of impervious area, and is now the second leading cause of stream impairment (Paul and Meyer 2001). Increases in imperviousness arise from the construction of buildings, roads, and paved areas, so rainwater infiltration is reduced, runoff increased, and stormwater flows rapidly off the land, accelerating the rate of transmission of water to the streams. As a result, peak flows arising during storm events are altered: the lag time, or time interval between the centre of mass of the storm and that of the hydrograph, is decreased by the construction of artificial paths (e.g. streets, roofs, storm sewers), so floods are larger in magnitude and peak more rapidly (Leopold 1968). Additionally, the average flood duration is decreased, and larger floods recur more frequently (see Paul and Meyer (2001) or Jacobson (2011) for a review). One exception to these effects occurs in urban areas with in-channel or detention storage, where flood peaks may actually be reduced in comparison with rural catchments (Sauer et al 1983).

Existing attribution research regarding the effects of urbanization on flooding is largely based on case-studies and paired catchment approaches. Graf (1977) considered the progressive suburbanisation in a catchment in Iowa City and found that it reduced the hydrograph lag time, while heightening the kurtosis (i.e. peakedness) of flood events. Smith et al. (2002) observed an urbanising catchment in the Charlotte metropolitan area of North 
710 Carolina, and found faster flood peak response in the urbanised section of the basin. White and Greer (2006) showed that increases in urban land from 9 to 37\% from 1966 to 2000 in Los Peñasquitos Creek, Southern California, heightened flood magnitudes substantially, despite a doubling of the area of riparian vegetation.

The paired catchment approach is considered one of the most robust methods for understanding the effects of land-use changes on streamflow (Salavati et al. 2016). Paired catchment studies function best in small catchments (e.g. $<1 \mathrm{~km}^{2}$ ) where the precipitation, soil/geology, topography, and other physical parameters can be controlled for, to ascertain similar conditions between the treatment and the control catchment. McCormick et al. (2009), for example, use a paired catchment approach in Maryland to detect trends in normalized annual maximum flows under coal mining versus un-mined conditions, and showed that peak runoff was higher and the centroid lag time shorter in the coal-mined basin in comparison with the un-mined basin. Other hydrologic modelling approaches like those described at the end of section 2.3.1 (attribution of flooding to climate), are also increasingly being used to detect the effects of land-use changes on flood flows.

Attribution of flooding to agriculture and other land-use changes

The field of attribution of changes in flooding to agriculture is also still an active area of research. As with the previous fields of attribution, it is possible to distinguish between 'soft' and 'hard' approaches ranging from case studies and paired catchment approaches to physically- and statistically-based modelling.

Case studies are generally based on time series of flood patterns and agricultural land use at the catchment-scale, which allow to draw inferences on the causes of change. Potter (1991) observes decreases in flood peaks and winter/spring flood volumes in a watershed in southwestern Wisconsin. The lack of any relationship between the hydrological and climatological variables, alongside the increase in row crops (which would normally heighten flood peaks) leads the author to speculate that the decreases must result from soil conservation practices such as strip cropping, contour ploughing, crop rotations, and forest management. These types of inference-based approaches have been largely abandoned in favour of paired catchment approaches. Paired catchment approaches are also commonly used in hydrological studies to detect any effects arising from changes in agricultural practices and/or forestry, such as thinning, clearcutting, or removal of riparian vegetation. 
southwest Iowa that were cultivated in corn, with different forms of tillage and conservation practices. The authors showed that the implementation of conservation tillage practices between the 1970s and 1990s reduced storm-driven runoff.

Modelling studies are also considered as a robust attribution approach for quantifying the effects of agriculture on flood distributions, and can be subdivided into two groups: physical and statistical modelling. Physically-based modelling allows the investigators to modulate the influence of different driving variables and measure the outcomes. Schilling et al. (2008) investigate the impacts of land use and land cover change on the water balance of an Iowan watershed using the Soil and Water assessment (SWAT) model. They show that increased corn production in place of grasslands (perennial cover) produces an increase in surface runoff due to the decreased soil infiltration. Seibert and McDonnell (2010) use changedetection methods based on the HBV model (Bergström 1992) in a headwater catchment in Oregon. By simulating daily discharge with precipitation and temperature inputs, they were able to determine that peak flows increased in response to forest clear-cutting.

Statistically-based modelling approaches are becoming increasingly popular in flood attribution. Zhang and Schilling (2006) use simple statistical trend analysis to infer the effect of agricultural practices (namely the conversion of perennial vegetation to seasonal row crops, especially soybean) on streamflow. They separate long-term daily flow time series in the Mississippi River Basin into stormflow (surface runoff) and base flow (groundwater discharge). The authors find that the overall trend towards increasing streamflow is caused by the baseflow component, and not the stormwater, suggesting that changes in soybean cover have not altered peak flows. New statistical approaches are now emerging to model the relationship between changing flood flows, precipitation and agriculture. Villarini and Strong (2014) modelled discharge as a function of observed annual precipitation and total harvested corn and soybean acreage using a gamma distribution. The goodness-of-fit of these models was such that the variations in discharge could be attributed to the corresponding changes in precipitation and agricultural intensity. Villarini et al. (2015) developed a modelling framework to evaluate the relative influence of precipitation and landuse/land cover on discharge in an agricultural watershed. They showed that the projected increases in high flows could be offset by reducing the fraction of the catchment that was cultivated (and converting it to perennial vegetation such as switchgrass). Slater et al. (2016b) used a similar approach to Villarini and Strong (2014) to develop dynamical seasonal flow forecasts using the most recently-available precipitation forecasts from the North American multi-model 
ensemble (NMME) (Kirtman et al. 2014). Statistically, the approach allows to disentangle the different drivers of changing flood magnitudes.

These different flood-attribution methods can be compared and contrasted. Bowling et al. (2000) observed changes in flood magnitude across 23 catchments in western Washington in response to changes in logging practices over a period of 70 years. They found increasing peak flows in the hydrological model but not in the paired catchment analysis, suggesting that the model was better able to filter out the natural variability and detect the signal in the data than the paired catchment approach. More recently, Salavati et al. (2016) consider the strengths and weaknesses of both methods (paired catchment and modelling) in 43 US river basins to detect the influence of urbanization on high and low flows. They found good agreement between the two approaches, although, surprisingly, they noted that the impacts of urbanization on the flow distributions was hard to generalize.

Changes in the magnitude and frequency of flood flows can thus be attributed to fluctuations in climate, water management, urbanisation, agriculture, and other types of landcover using a variety of approaches that range from 'soft' to 'hard'. Future research in this area will undoubtedly seek to develop the most statistically robust techniques for disentangling the different drivers of changing flood hazards and, ultimately, to achieve the different ‘ingredients’ of the attribution process, as described by Merz (2012).

\section{Moving Forward}

Much effort has been dedicated to the quantification of changes in flood events across the United States and to the examination of their possible causal mechanisms. The increasing availability of hydro-climatologic data across the globe, including satellite-based estimates of precipitation (Quintero et al. 2016), land surface temperature (Parinussa et al. 2016) river discharge (Gleason and Smith, 2014) and basin-scale water storage (Reager et al. 2014), is leading to continual improvements in flood hazard estimates and projections (García-Pintado et al. 2015). Moving forward, it is now becoming increasingly critical to shift the paradigm of flood analysis from the sole detection of changes in flood frequency to the attribution and projection of those changes. This paradigm shift has major implications from both a scientific and a practical perspective. From a scientific standpoint, the attribution of changes in flood peak records will lead to an improved understanding of the physical processes that are responsible for the interannual variability in these records, thus advancing the hydrologic sciences. From an engineering perspective, the sole detection of changes is no longer a viable 
807

808

809

810

811

812

option as past flood records are no longer representative of the future (e.g. Milly et al. 2008), and the extrapolation of trend lines into the future is technically hazardous, as it is not known when or where the next step changes may occur. However, if we can understand what factors are responsible for the observed changes, and project them using global climate model predictions and projections, then we will be better positioned to provide estimates of future flood design.
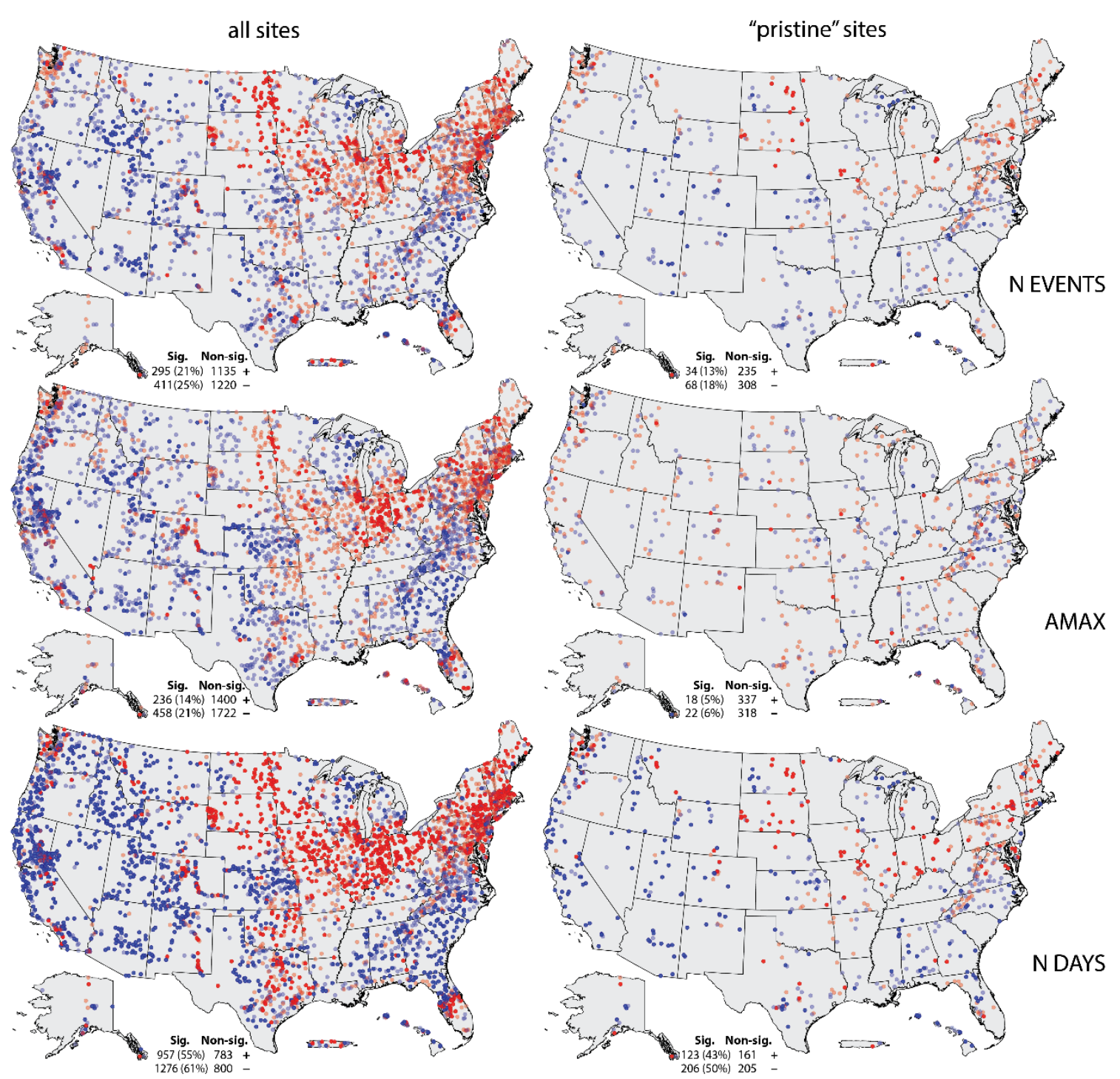

Figure 1. Trends in flooding across the USA (water years 1965-2015). Flood trends are expressed in terms of the number of flood events (N EVENTS), flood magnitude (AMAX) and number of flood days (N DAYS), from the top to the bottom row, respectively.

817 Increasing trends are indicated in red, decreasing trends in blue, with the significant trends (at 818 the 5\% level) represented as solid colours, and the non-significant trends as transparent 
819 colours. The left-hand column shows all gauging stations, and the right-hand column is a 820 subset of climate-sensitive sites, selected using the GAGES-II reference classification 821 (Falcone et al. 2010). The tables in the bottom of each panel indicate the number of sites with 822 significant and non-significant trends, separated by their sign (increases “+” and decreases “823 "). 


\section{References}

Alila, Y., \& Mtiraoui, A. (2002). Implications of heterogeneous flood-frequency distributions on traditional stream-discharge prediction techniques, Hydrological Processes, 16, 1065-1084.

Armstrong, W.H., Collins, M.J. \& Snyder, N.P. (2012). Increased frequency of low-magnitude floods in New England. Journal of the American Water Resources Association, 01930, 1-15. http://doi.org/10.1111/j.1752-1688.2011.00613.x/full

Armstrong, W.H. (2013). Hydroclimatic flood trends in the northeastern United States and linkages with large-scale atmospheric circulation patterns. Hydrological Sciences, http://doi.org/10.1080/02626667.2013.862339

Barnett, T. P., Adam, J. C., \& Lettenmaier, D. P. (2005). Potential impacts of a warming climate on water availability in snow-dominated regions. Nature, 438(7066), 303-9. http://doi.org/10.1038/nature04141

Berghuijs, W.R., Woods, R.A., Hutton, C.J., \& Sivapalan, M. (2016). Dominant flood generating mechanisms across the United States. Geophysical Research Letters, n/a-n/a. http://doi.org/10.1002/2016GL068070

Bergström, S. (1992). The HBV model: Its structure and applications. Swedish Meteorological and Hydrological Institute. http://tinyurl.com/zkq4p5r

Blöschl, G., \& Sivapalan, M. (1995). Scale Issues in Hydrological Modeling: A Review. Hydrological Processes, 9(3-4), 251-290. http://doi.org/10.1002/hyp.3360090305

Booth, D. B. (1991). Urbanization and the natural drainage system--impacts, solutions, and prognoses. The Northwest Environmental Journal, 7:93-118.

Booth, D.B., and Jackson, C.R. (1997). Urbanization of aquatic systems: degradation thresholds, stormwater detection, and the limits of mitigation. Journal of the American Water Resources Association, 33(5)1077-1090

Bowling, L. C., Storck, P., \& Lettenmaier, D. P. (2000). Hydrologic effects of logging in western Washington, United States. Water Resources Research, 36(11), 3223-3240. http://doi.org/10.1029/2000WR900138

Brillinger, D.R. (2001). Time series: data analysis and theory. In: Classics in Applied Mathematics (Book 36), Siam.

Cheng, L., A. AghaKouchak, E. Gilleland, and R. W. Katz (2014), Non-stationary extreme value analysis in a changing climate, Clim. Change, 127(2), 353-369, http://doi.org/10.1007/s10584-014-1254-5

Choi, O., \& Fisher, A. (2003). The impacts of socioeconomic development and climate change on severe weather catastrophe losses: Mid-Atlantic Region (MAR) and the US. Climatic Change, 149-170. http://doi.org/10.1023/A:1023459216609

Collins, M. J. (2009). Evidence for Changing Flood Risk in New England Since the Late 20th Century. Journal of the American Water Resources Association, 45(2), 279-290. http://doi.org/10.1111/j.1752-1688.2008.00277.x

Collins, M.J., Kirk, J.P., Pettit, J., DeGaetano, A.T., McCown, M.S., Peterson, T.C., Means, T.N., Zhang, X. (2014). Annual floods in New England (USA) and Atlantic Canada: synoptic climatology and generating mechanisms. Physical Geography 35(3):195- 219. http://doi.org/10.1080/02723646.2014.888510

Cunnane, C. (1973). A particular comparison of annual maxima and partial duration series methods of flood frequency prediction. Journal of Hydrology 18:257-271. http://doi.org/10.1016/00221694(73)90051-6

Davis Todd, C. E., Goss, A. M., Tripathy, D., \& Harbor, J. M. (2007). The Effects of Landscape Transformation in a Changing Climate on Local Water Resources. Physical Geography, 28(November), 21-36. http://doi.org/10.2747/0272-3646.28.1.21Dettinger, M. D., \& Cayan, 
D. R. (1995). Large-scale atmospheric forcing of recent trends toward early snowmelt runoff in California. Journal of Climate, 8(3), 606-623. http://tenaya.ucsd.edu/ dettinge/roos.pdf

Diehl, T., and K.W. Potter, (1987). Mixed flood distribution in Wisconsin, in Hydrologic Frequency Modeling, edited by V.P. Singh, 213-226.

Douglas, E.M., Vogel, R. M., \& C. N. Kroll. (2000). Trends in floods and low flows in the United States: impact of spatial correlation. Journal of Hydrology 240.1: 90-105. http://dx.doi.org/10.1016/S0022-1694(00)00336-X

Downton, M.W., Miller, J.Z.B. \& Pielke, R.A. (2005). Reanalysis of US National Weather Service flood loss database. Nat. Hazards Rev. 6, 13-22

Duan, Q., Schaake, J., Andreassian, V., Franks, S., Goteti, G., Gupta, H. V., ... Wood, E. F. (2006). Model Parameter Estimation Experiment (MOPEX): An overview of science strategy and major results from the second and third workshops. Journal of Hydrology, 320(1-2), 3-17. http://doi.org/10.1016/j.jhydrol.2005.07.031

Dupuis, D. J. (1998). Exceedances over High Thresholds: A Guide to Threshold Selection. Extremes, 1(3), 251-261. http://doi.org/10.1023/A:1009914915709

Dury, G. H. (1961). Bankfull discharge; an example of its statistical relationships. International Association of Scientific Hydrology. Bulletin, 6:3, 48-55, http://doi.org/10.1080/02626666109493230

Echeverria J.D., Barrow P, Roos-Collins R. (1989). Rivers at risk: the concerned citizen's guide to hydropower. Washington (DC): Island Press

Falcone, J.A., Carlisle, D.M., Wolock, D.M., \& Meador, M.R. (2010). GAGES: A stream gage database for evaluating natural and altered flow conditions in the conterminous United States. Ecology, 91(2), 621-621. http://doi.org//10.1890/09-0889.1

Field, C.B., Barros, V., Stocker, T.F., Dahe, Q., \& (Ed.). (2012). Managing the Risks of Extreme Events and Disasters to Advance Climate Change Adaptation: Special Report of the Intergovernmental Panel on Climate Change (SREX). (C. B. Field, V. Barros, T. F. Stocker, \& Q. Dahe, Eds.). Cambridge: Cambridge University Press. http://doi.org/10.1017/CBO9781139177245

García-Pintado, J., D. C. Mason, S. L. Dance, H. L. Cloke, J. C. Neal, J. Freer, and P. D. Bates (2015), Satellite-supported flood forecasting in river networks: A real case study, J. Hydrol., 523, 706-724, http://doi.org/10.1016/j.jhydrol.2015.01.084

Georgakakos, A., Fleming, P., Dettinger, M., Peters-Lidard, C., Richmond, T.C., Reckhow, K., White, K., \& D. Yates. (2014). Water resources. In: Climate Change Impacts in the United States: The Third National Climate Assessment, J.M. Melillo, T.C. Richmond, and G.W. Yohe (Editors). U.S. Global Change Research Program, pp. 69-112, http://doi.org/10.7930/J0G44N6T

Gleason, C. J., and L. C. Smith (2014), Toward global mapping of river discharge using satellite images and at-many-stations hydraulic geometry., Proc. Natl. Acad. Sci. U.S.A., 111(13), 4788-91, http://doi.org/10.1073/pnas.1317606111.

Graf, W. L. (1977). Network Characteristics in Suburbanizing Streams. Water Resources Research, 13(2), 459-463. http://doi.org/10.1029/WR013i002p00459

Graf, W. L. (1999). Dam nation: A geographic census of American dams and their large-scale hydrologic impacts. Water Resources Research, 35(4), 1305. http://doi.org/10.1029/1999WR900016

Graf, W.L. (2006). Downstream hydrologic and geomorphic effects of large dams on American rivers. Geomorphology 79, 336-360.

Grego, J.M., \& Yates, P.A. (2010). Point and standard error estimation for quantiles of mixed flood distributions, Journal of Hydrology, 391, 289-301. 
Grego, J.M., Yates, P.A., \& Mai, K. (2015). Standard error estimation for mixed flood distributions with historic maxima, Environmetrics, 26, 229-242.

Gregory, K. J., \& Park, C. (1974). Adjustment of river channel capacity downstream from a reservoir. Water Resources Research, 10(4), 870-873. http://doi.org/10.1029/WR010i004p00870

Groisman, P.Y., Knight, R.W., \& Karl. T.R. (2001). Heavy precipitation and high streamflow in the contiguous United States: Trends in the twentieth century. Bulletin of the American Meteorological Society 82, no. 2: 219-246. http://doi.org/10.1175/15200477(2001)082<0219:HPAHSI>2.3.CO;2

Gutowski, W.J., Hegerl, G.C., Holland, G.J., Knutson, T.R., Mearns, L.O., Stouffer, R.J., Webster, P.J., Wehner, M.F., \& Zwiers F.W. (2008). Causes of observed changes in extremes and projections of future changes. In: Weather and Climate Extremes in a Changing Climate: Regions of Focus: North America, Hawaii, Caribbean, and U.S. Pacific Islands [Karl, T.R., G.A. Meehl, C.D. Miller, S.J. Hassol, A.M. Waple, and W.L. Murray (eds.)]. Synthesis and Assessment Product 3.3. U.S. Climate Change Science Program, Washington, DC, pp. 81-116

Hamlet, A. F., \& Lettenmaier, D. P. (2007). Effects of 20th century warming and climate variability on flood risk in the western U.S. Water Resources Research, 43(6), n/a-n/a. http://doi.org/10.1029/2006WR005099

Harrigan, S., Murphy, C., Hall, J., Wilby, R. L., \& Sweeney, J. (2014). Attribution of detected changes in streamflow using multiple working hypotheses. Hydrology and Earth System Sciences, 18(5), 1935-1952. http://doi.org/10.5194/hess-18-1935-2014

Helsel, D. R., \& Hirsch, R. M. (1992). Chapter A3 - Statistical Methods in Water Resources, Book 4 Hydrologic Analysis and Interpretation. In Techniques of Water Resources Investigations of the United States Geological Survey, Reston, VA. http://pubs.usgs.gov/twri/twri4a3/pdf/chapter12.pdf

Hirschboeck, K. K. (1987). Hydroclimatically defined mixed distributions in partial duration flood series. Hydrologic Frequency Modelling, V. P. Singh Ed., D. Reidel Publishing Company, 199-212.

Hirschboeck, K. K. (1988). Flood hydroclimatology. Flood Geomorphology, V. R. Baker, R. C. Kockel, and P. C. Patton, Eds., John Wiley \& Sons, 27-49.

Hirschboeck, K.K. (1991). Climate and floods, in National Water Summary 1988-1989: Hydrologic Events and Floods and Droughts: U.S. Geological Survey Water

Hirsch, R.M., \& Ryberg, K.R. (2012). Has the magnitude of floods across the USA changed with global CO 2 levels? Hydrological Sciences Journal, 57(1), 1-9. http://doi.org/10.1080/02626667.2011.621895

Hodgkins, G.A., Dudley, R., \& Huntington, T. (2003). Changes in the timing of high river flows in New England over the 20th Century. Journal of Hydrology, 278(1-4), 244-252. http://doi.org/10.1016/S0022-1694(03)00155-0

Hodgkins, G. A. (2010). Historical Changes in Annual Peak Flows in Maine and Implications for Flood-Frequency Analyses. USGS, Scientific Investigations Report 2010-5094 http://doi.org/10.1111/j.1752-1688.2008.00277.x.Hamed

Jacobson, C. R. (2011). Identification and quantification of the hydrological impacts of imperviousness in urban catchments: A review. Journal of Environmental Management, 92(6), 1438-1448. http://doi.org/10.1016/j.jenvman.2011.01.018

Janssen, E., Wuebbles, D., \& Kunkel, K. E. (2014). Observational and Model based Trends and Projections of Extreme Precipitation over the Contiguous United States. Earth's Future, 115. http://doi.org/10.1002/2013EF000185.Received 
Jarrett, R.D., and Costa, J.E. (1988). Evaluation of the flood hydrology in the Colorado Front Range using precipitation, streamflow, and paleoflood data for the Big Thompson River basin: U.S. Geological Survey Water-Resources Investigations Report 87-4117, 37 p.

Jung, I. W., \& Chang, H. (2011). Assessment of future runoff trends under multiple climate change scenarios in the Willamette River Basin, Oregon, USA. Hydrological Processes, 25(2), 258277. http://doi.org/10.1002/hyp.7842

Karl, T.R., \& Knight, R.W. (1998). Secular trends of precipitation amount, frequency, and intensity in the United States Bulletin of the American Meteorological society 79.2: 231-241.

Karl, T. R., Melillo, J. M., \& Peterson, T. C. (2009). Global Climate Change Impacts in the United States. Society (Vol. 54). http://www.globalchange.gov/usimpacts

Katz, R. W., \& Brown, B. G. (1992). Extreme events in a changing climate: Variability is more important than averages. Climatic Change, 21(3), 289-302. http://doi.org/10.1007/BF00139728

Kendall, M.G. (1975). Rank correlation Methods. London, UK: Griffin

Kondolf, G. M. (1997). Hungry Water: Effects of Dams and Gravel Mining on River Channels. Environmental Management, 21(4), 533-51. http://www.ncbi.nlm.nih.gov/pubmed/9175542

Kousky, C., \& Michel-Kerjan, E. (2015). Examining flood insurance claims in the United States: Six key findings. Journal of Risk and Insurance, http://doi.org/10.1111/jori.12106

Kirby, W. (1969). On the Random Occurrence of Major Floods. Water Resources Research, 5(4), 778-784. http://doi.org/10.1029/WR005i004p00778

Kirtman, B. P., Min, D., Infanti, J. M., Kinter, J. L., Paolino, D. a., Zhang, Q., ... Wood, E. F. (2014). The North American multimodel ensemble: Phase-1 seasonal-to-interannual prediction; phase-2 toward developing intraseasonal prediction. Bulletin of the American Meteorological Society, 95(April), 585-601. http://doi.org/10.1175/BAMS-D-12-00050.1

Klemeš, V. (1974). Some problems in pure and applied stochastic hydrology. Miscellaneous Publication No. 1275, U.S. Department of Agriculture, 2-15.

Klemeš, V. (1993). Probability of extreme hydrometeorological events-A different approach, in Extreme Hydrological Events: Precipitation, Floods and Droughts, edited by Z. W. Kundzewicz et al., IAHS Publ., 213, 167-176.

Knowles N, \& Cayan DR. (2002). Potential effects of global warming on the Sacramento/San Joaquin watershed and the San Francisco estuary. Geophysical Research Letters 29(18): 1891, 1810. http://doi.org/1029/2001GL014339

Knox, J. C. (2001). Agricultural influence on landscape sensitivity in the Upper Mississippi River Valley. Catena, 42(2-4), 193-224. http://doi.org/10.1016/S0341-8162(00)00138-7

Kramer, L.A., Burkart, M.R., Meek, D.W., Jaquis, R. J., \& James D.E. (1999), Field-scale watershed evaluations in deep-loess soils: II. Hydrologic responses to different agricultural land management systems, J. Soil Water Conserv., 54, 705-710.

Kundzewicz, Z.W., Robson, A.J. (2004). Change detection in hydrological records-a review of the methodology/Revue méthodologique de la détection de changements dans les chroniques hydrologiques. Hydrol. Sci. J. 49 (1), 7-19. http://dx.doi.org/10.1623/hysj.49.1.7.53993

Kundzewicz, Z. W., Graczyk, D., Maurer, T., Pińskwar, I., Svensson, C., \& Szwed, M. (2005). Trend detection in river flow series : 1 . Annual maximum flow. Hydrological Sciences Journal, 50(5).

Kunkel, K.E., Andsager, K., \& Easterling D.R. (1999). Long-term trends in extreme precipitation events over the conterminous United States and Canada. Journal of climate 12.8: 2515-2527. http://doi.org/http://dx.doi.org/10.1175/1520-0442(1999)012<2515:LTTIEP>2.0.CO;2 
Kunkel, K. E., Karl, T. R., Brooks, H., Kossin, J., Lawrimore, J. H., Arndt, D., ... Wuebbles, D. (2013). Monitoring and understanding trends in extreme storms: State of knowledge. Bulletin of the American Meteorological Society, 94(4), 499-514. http://doi.org/10.1175/BAMS-D-1100262.1

Lang, M., Ouarda, T.M.B.J., \& Bobée, B. (1999). Towards operational guidelines for over- threshold modeling. Journal of Hydrology 225:103-117

Langbein, W.B. (1949). Annual floods and the partial-duration flood series. American Geophysical Union Transactions, 30(6), 879-881. http://doi.org/10.1029/TR030i006p00879

Leadbetter, M. R. (1991). On a basis for "Peaks over Threshold" modeling. Statistics and Probability Letters, 12(4), 357-362. http://doi.org/10.1016/0167-7152(91)90107-3

Leopold, L. B. (1962). A national network of hydrologic bench marks. Circular 460-B, 4. United States Geological Survey.

Leopold, L. B., Wolman, M. G., \& Miller, J. (1964). Fluvial processes in geomorphology. San Francisco.

Leopold, L. (1968). Hydrology for urban land planning: A guidebook on the hydrologic effects of urban land use. Geological Survey Circular 554, 1-18. http://enviro.lclark.edu/resources/Tryon/Water/Hydrology.pdf

Lins, H.F., \& Slack, J.R. (1999). Streamflow trends in the United States. Geophysical Research Letters, 26(2), 227-230. http://dx.doi.org/10.1029/1998GL900291

Lins, H.F., \& Slack, J.R. (2005). Seasonal and Regional Characteristics of U.S. Streamflow Trends in the United States from 1940 to 1999. Physical Geography, 26(6), 489-501. http://doi.org/10.2747/0272-3646.26.6.489

Lins, H. F. (2012). USGS Hydro-Climatic Data Network 2009 (HCDN-2009) US Geological Survey Fact Sheet 3047.4

Lombard, F. (1987). Rank test for changepoint problems. Biometrika, 74(3), 615-624. http://doi.org/10.1093/biomet/74.3.615

Mallakpour, I., \& Villarini, G. (2015a). A simulation study to examine the sensitivity of the Pettitt test to detect abrupt changes in mean. Hydrological Sciences Journal, (January), 37-41. http://doi.org/10.1016/j.jhazmat.2013.02.017

Mallakpour, I., \& Villarini, G. (2015b). The changing nature of flooding across the central United States. Nature Climate Change (February), 1-5. http://doi.org/10.1038/NCLIMATE2516

Mallakpour, I., \& Villarini, G. (2015). A simulation study to examine the sensitivity of the Pettitt test to detect abrupt changes in mean. Hydrological Sciences Journal, (January), 37-41. http://doi.org/10.1016/j.jhazmat.2013.02.017

Mallakpour, I., \& Villarini, G. (2015). The changing nature of flooding across the central United States. Nature Climate Change (February), 1-5. http://doi.org/10.1038/NCLIMATE2516

Mallakpour, I., \& Villarini, G. (2016). Investigating the relationship between the frequency of flooding over the central United States and large-scale climate. Advances in Water Resources. http://doi.org/10.1016/j.advwatres.2016.04.008

Mann, H.B. (1945). Nonparametric tests against trend. Econometrica 13:245-259.

McCabe, G.J. \& Wolock, D.M. (2002). A step increase in streamflow in the conterminous United States. Geophysical Research Letters 29.24. http://doi.org/10.1029/2002GL015999

McCabe, G.J., Clark, M.P. (2005). Trends and variability in snowmelt runoff in the western United States. Journal of Hydrometeorology 6:476-482.

McCormick, B.C., Eshleman, K.N., Griffith, J.L., \& Townsend, P.A. (2009). Detection of flooding responses at the river basin scale enhanced by land use change. Water Resources Research, 45(8), 1-15. http://doi.org/10.1029/2008WR007594 
Merz, R., \& G. Blöschl (2003). A process typology of regional floods, Water Resour. Res., 39(12), 1340, doi:10.1029/2002WR001952.

Merz, B., Vorogushyn, S., Uhlemann, S., Delgado, J., \& Hundecha, Y. (2012). HESS Opinions "More efforts and scientific rigour are needed to attribute trends in flood time series." Hydrology and Earth System Sciences, 16(5), 1379-1387. http://doi.org/10.5194/hess-16-1379-2012

Milly, P.C.D, Betancourt, J., Falkenmark, M., Hirsch, R.M., Kundzewicz, Z.W., Lettenmaier, D.P., and Stouffer, R.J. (2008). Stationarity is dead: Whither water management?: Science, v. 319, p. 573-574 http://doi.org/10.1126/science.1151915

Murdoch, P.S., McHale, M.R., Mast, M.A., and Clow, D.W. (2005). The U.S. Geological Survey Hydrologic Benchmark Network: U.S. Geological Survey Fact Sheet 2005-3135, 6 p., 4 figs.

Murphy, P.J. (2001). Evaluation of mixed-population flood-frequency analysis, Journal of Hydrologic Engineering, 6(1), 62-70.

National Climate Data Center (NCDC), (2016), Billion-Dollar Weather and Climate Disasters, http://www.ncdc.noaa.gov/billions/events

National Research Council. (2004). Assessing the National Streamflow Information Program. Washington, DC: The National Academies Press, http://doi.org/10.17226/10967

NOAA National Weather Service (2016), Hydrologic Information Center - Flood Loss Data http://www.nws.noaa.gov/hic/

Nayak, M. A., \& Villarini, G. (2016). Evaluation of the capability of the Lombard test in detecting abrupt changes in variance. Journal of Hydrology, 534, 451-465. http://doi.org/10.1016/j.jhydrol.2016.01.016

Office of Services (2016). U.S. Natural Hazard Statistics, compiled by the Office of Climate, Water, and Weather Services, NOAA; see the 76-year list of severe weather fatalities http://www.nws.noaa.gov/om/hazstats/resources/weather_fatalities.pdf

Parinussa, R. M., V. Lakshmi, F. M. Johnson, and A. Sharma (2016), A new framework for monitoring flood inundation using readily available satellite data, Geophys. Res. Lett., 43(6), n/a-n/a, http://doi.org/10.1002/2016GL068192.

Paul, M. J., \& Meyer, J. L. (2001). Streams in the urban landscape. Annual Review of Ecology and Systematics, 32, 333-365. http://doi.org/doi:10.1146/annurev.ecolsys.32.081501.114040

Pettitt, A.N. (1979). A non-parametric approach to the change-point problem. Applied Statistics 28: $126-135$

Petrow, T., \& Merz, B. (2009). Trends in flood magnitude, frequency and seasonality in Germany in the period 1951-2002. Journal of Hydrology, 371(1-4), 129-141. http://doi.org/10.1016/j.jhydrol.2009.03.024Pielke Jr, R.A., \& Downton, M.W. (2000) Precipitation and damaging floods: Trends in the United States, 1932-97. Journal of Climate 13.20: 3625-3637.

Poff, N., Allan, J., Bain, M., \& Karr, J. (1997). The natural flow regime. BioScience, 47(11), 769784. Retrieved from http://www.jstor.org/stable/1313099

Potter, K. W. (1991). Hydrological impacts of changing land management practices in a moderatesized agricultural catchment, Water Resour. Res., 27(5), 845-855. http://doi.org/10.1029/91WR00076

Praskievicz, S., \& Chang, H. (2011). Impacts of Climate Change and Urban Development on Water Resources in the Tualatin River Basin, Oregon. Annals of the Association of American Geographers, 101(2), 249-271. http://doi.org/10.1080/00045608.2010.544934

Pryor, S. C., Howe, J. A., \& Kunkel, K. E. (2009). How spatially coherent and statistically robust are temporal changes in extreme precipitation in the contiguous USA ? International Journal of Climatology, 45(March 2008), 31-45. http://doi.org/10.1002/joc.1696 
Quintero, F., W. F. Krajewski, R. Mantilla, S. Small, and B.-C. Seo (2016), A Spatial-Dynamical Framework for Evaluation of Satellite Rainfall Products for Flood Prediction, $J$. Hydrometeorol., 17(8), 2137-2154, http://doi.org/10.1175/JHM-D-15-0195.1

Reager, J. T., B. F. Thomas, and J. S. Famiglietti (2014), River basin flood potential inferred using GRACE gravity observations at several months lead time, Nat. Geosci., 7(8), 588-592, http://doi.org/10.1038/ngeo2203

Rossi, F., Fiorentino, M., \& Versace, P. (1984). Two-component extreme value distribution for flood frequency analysis. Water Resources Research 20, 847-856.

Rougé, C., Ge, Y., \& Cai, X. (2013). Detecting gradual and abrupt changes in hydrological records. Advances in Water Resources, 53, 33-44. http://doi.org/10.1016/j.advwatres.2012.09.008

Salas, J.D. (1993). Analysis and modeling of hydrologic time series. Handbook of hydrology 19 (1993): 1-72.

Salavati, B., Oudin, L., Furusho-Percot, C., Ribstein, P. (2016). Modelling approaches to detect landuse changes: Urbanization analyzed on a set of 43 US catchments, Journal of Hydrology, http:// dx.doi.org/10.1016/j.jhydrol.2016.04.010

Sauer, V.B., Thomas, W.O., Stricker, V.A., \& Wilson, K.V. (1983), Flood characteristics of urban watersheds in the United States, U.S. Geol. Water Supply Pap., 2207.

Schaake, J., Cong, S., \& Duan Q. (2006). The US MOPEX data set. IAHS publication 307: 9.

Schilling, K.E., Jha, M.K., Zhang, Y.-K., Gassman, P.W., \& Wolter C.F. (2008), Impact of land use and land cover change on the water balance of a large agricultural watershed: Historical effects and future directions, Water Resour. Res., 44, W00A09, http://doi.org/10.1029/2007WR006644

Schmidt, J. C., \& Wilcock, P. R. (2008). Metrics for assessing the downstream effects of dams. Water Resources Research, 44(4), 1-19. http://doi.org/10.1029/2006WR005092

Seibert, J., \& McDonnell, J. J. (2010). Land-cover impacts on streamflow: a change-detection modelling approach that incorporates parameter uncertainty. Hydrological Sciences Journal, 55(3), 316-332. http://doi.org/10.1080/02626661003683264

Shaw, S. B., \& Riha, S. J. (2011). Assessing possible changes in flood frequency due to climate change in mid-sized watersheds in New York State, USA. Hydrological Processes, 25(16), 2542-2550. http://doi.org/10.1002/hyp.8027

Singh, V.P., Wang, S.X., \& Zhang L. (2005). Frequency analysis of nonidentically distributed hydrologic flood data, Journal of Hydrology, 307, 175-195

Slack, J. R., \& Landwehr J.M. (1992) Hydro-Climatic Data Network: A U.S. Geological Survey streamflow data set for the United States for the study of climate variations, 1974-1988. U.S. Geological Survey Rep. 92-129, 193 pp

Slater, L. J., \& Singer, M. B. (2013). Imprint of climate and climate change in alluvial riverbeds: Continental United States, 1950-2011. Geology, 41(5), 595-598. http://doi.org/10.1130/G34070.1

Slater, L.J., Singer, M.B., \& Kirchner, J.W. (2015). Hydrologic versus geomorphic drivers of trends in flood hazard. Geophysical Research Letters, 42, 1-7. http://doi.org/10.1002/2014GL062482

Slater, L.J. (2016). To what extent have changes in channel capacity contributed to flood hazard trends in England and Wales? Earth Surface Processes and Landforms, n/a-n/a. http://doi.org/10.1002/esp.3927

Slater, L.J. \& Villarini, G. (2016a). Recent trends in U.S. flood risk. Geophysical Research Letters. http://doi.org/10.1002/2016GL071199

Slater, L.J., Villarini, G., Bradley, A. \& Vecchi, G. (2016b, under review, Climate Dynamics) A statistical/dynamical framework for discharge forecasting over Iowa using precipitation and harvested acreage 
Smith, R. L. (1984). Threshold methods for sample extremes. In Statistical extremes and applications (pp. 621-638). Springer Netherlands. http://doi.org/10.1007/978-94-017-30693_48

Smith, J.A., \& Karr, A.F. (1986). Flood Frequency Analysis Using the Cox Regression Model. Water Resources Research, 22(6), 890-896. http://doi.org/10.1029/WR022i006p00890

Smith, A.B., \& Katz, R.W. (2013). US billion-dollar weather and climate disasters: Data sources, trends, accuracy and biases. Natural Hazards, 67(2), 387-410. http://doi.org/10.1007/s11069013-0566-5

Smith, J.A., Baeck, M.L., Villarini, G., \& Krajewski, W.F. (2010). The hydrology and hydrometeorology of flooding in the Delaware River Basin. Journal of Hydrometeorology, 11:841-859. http://doi.org/10.1175/2010JHM1236.1

Smith, J.A., Baeck, M.L., Morrison, J.E., Sturdevant-Rees, P., Turner-Gillespie, D.F., \& Bates, P.D. (2002). The Regional Hydrology of Extreme Floods in an Urbanizing Drainage Basin. Journal of Hydrometeorology, 3(3), 267-282. http://doi.org/10.1175/15257541(2002)003<0267:TRHOEF>2.0.CO;2

Smith, J.A., Villarini, G., \& Baeck M.L. (2011). Mixture distributions and the climatology of extreme rainfall and flooding in the Eastern US, Journal of Hydrometeorology, 12(2), 294-309.

Stover, S., \& Montgomery, D.R. (2001). Channel change and flooding, Skokomish River, Washington. Journal of Hydrology, 243(3-4), 272-286. http://doi.org/10.1016/S00221694(00)00421-2

Svensson, C., Kundzewicz, Z.W., Maurer, T. (2005). Trend detection in river flow series: 2. Flood and low-flow index series. Hydrological Sciences Journal 50:811-824.

Todhunter, P.E. (2012). Uncertainty of the assumptions required for estimating the regulatory flood: Red River of the North, Journal of Hydrologic Engineering, 17(9), 1011-1020

Trenberth, K. (2011).Changes in precipitation with climate change. Climate Research, 47(1), 123138. http://doi.org/10.3354/cr00953

US Census Bureau. (2010). http://www.census.gov

U.S. Interagency Advisory Committee on Water Data. (1982). Guidelines for determining flood flow frequency, Bulletin 17-B of the Hydrology Subcommittee: Reston, Virginia, U.S. Geological Survey, Office of Water Data Coordination [183 p.].

Van Steeter, M.M., \& Pitlick, J. (1998). Geomorphology and endangered fish habitats of the upper Colorado River: 1 . Historic changes in streamflow, sediment load, and channel morphology. Water Resources Research, 34(2), 287-302. http://doi.org/10.1029/97WR02766

Villarini, G. (2016). On the seasonality of flooding across the continental United States, Advances in Water Resources, 87, 80-91.

Villarini, G., Serinaldi, F., Smith, J.A., \& Krajewski, W.F. (2009). On the stationarity of annual flood peaks in the continental United States during the 20th century. Water Resources Research, 45(8), 1-17. http://doi.org/10.1029/2008WR007645

Villarini, G., \& Smith, J.A. (2010). Flood peak distributions for the eastern United States. Water Resources Research, 46(6), 1-17. http://doi.org/10.1029/2009WR008395

Villarini, G., Smith, J.A., Baeck, M.L., \& Krajewski, W.F. (2011). Examining Flood Frequency Distributions in the Midwest U.S. Journal of the American Water Resources Association, 47(3), 447-463. http://doi.org/10.1111/j.1752-1688.2011.00540.x

Villarini, G., \& Smith, J.A. (2013). Flooding in Texas: Examination of temporal changes and impacts of tropical cyclones, Journal of the American Water Resources Association, 49(4), 825-837.

Villarini, G., Goska, R., Smith, J.A., \& Vecchi, G.A. (2014). North Atlantic tropical cyclones and U.S. flooding, Bulletin of the American Meteorological Society, 95(9), 1381-1388. 
Villarini, G., \& Strong, A. (2014). Roles of climate and agricultural practices in discharge changes in an agricultural watershed in Iowa. Agriculture, Ecosystems \& Environment, 188, 204-211. http://doi.org/10.1016/j.agee.2014.02.036

Villarini, G., Scoccimarro, E., White, K.D., Arnold, J.R., Schilling, K.E., \& Ghosh, J. (2015). Projected Changes in Discharge in an Agricultural Watershed in Iowa. Journal of the American Water Resources Association, 51(5), 1361-1371. http://doi.org/10.1111/17521688.12318

Vogel, R.M., Yaindl, C., \& Walter, M. (2011). Nonstationarity: Flood magnification and recurrence reduction factors in the United States. Journal of the American Water Resources Association, 47(3), 464-474. http://doi.org/10.1111/j.1752-1688.2011.00541.x

Walsh, J., Wuebbles, D., Hayhoe, K., Kossin, J., Kunkel, K., Stephens, G., Thorne, P., Vose, R., Wehner, M., Willis, J., Anderson, D., Doney, S., Feely, R., Hennon, P., Kharin, V., Knutson, T., Landerer, F., Lenton, T., Kennedy, J., \& Somerville, R. (2014). Ch. 2: Our Changing Climate. Climate Change Impacts in the United States: The Third National Climate Assessment, J. M. Melillo, Terese (T.C.) Richmond, and G. W. Yohe, Eds., U.S. Global Change Research Program, 19-67. http://doi.org/10.7930/J0KW5CXT.

Wang, G., and Schimel, D. (2003). Climate change, climate modes, and climate impacts. Annual Review of Environment and Resources 28.1: 1-28.

Waylen, P. (1991). Modeling the effects of tropical cyclones on flooding in the Santa Fe River basin, Florida. GeoJournal, 23, 361-373.

Waylen, P., and M. Woo (1982). Prediction of annual floods generated by mixed processes, Water Resources Research, 18(4), 1283-1286.

Webb RH, Betancourt JL. (1992). Climatic variability and flood frequency of the Santa Cruz River, Pima County, Arizona. U.S. Geological Survey Water Supply Paper 2379: 40.

White, M.D., \& Greer, K.A. (2006). The effects of watershed urbanization on the stream hydrology and riparian vegetation of Los Peñasquitos Creek, California. Landscape and Urban Planning, 74(2), 125-138. http://doi.org/10.1016/j.landurbplan.2004.11.015

Whitfield, P.H. (2013). Is "Centre of Volume” a robust indicator of changes in snowmelt timing? Hydrological Processes, 27(18), 2691-2698. http://doi.org/10.1002/hyp.9817

Whitfield, P., \& Burn, D. (2012). Reference hydrologic networks I. The status and potential future directions of national reference hydrologic networks for detecting trends. Hydrological Sciences Journal, (January 2013), 37-41. http://doi.org/10.1080/02626667.2012.728706

Wilby R.L. 2006. When and where might climate change be detectable in UK river flows? Geophysical Research Letters 33: L19407 http://doi.org/10.1029/2006GL027552

Williams, G. P., \& Wolman, M. G. (1984). Downstream Effects of Dams on Alluvial Rivers. In Geological Survey Professional Paper 1286. (pp. 1-83). Washington, D.C.: U.S. Government Printing Office.

Yue, S., Pilon, P., \& Cavadias G. (2002), Power of the Mann-Kendall and Spearman's rho tests for detecting monotonic trends in hydrological series, J. Hydrol., 259, 254-271. http://doi.org/10.1016/S0022-1694(01)00594-7

Zhang, Y. K., \& Schilling, K.E. (2006), Increasing streamflow and baseflow in Mississippi River since the 1940s: Effect of land use change, J. Hydrol., 324, 412-422 